\title{
Erratum to: Outer membrane protein C (OmpC) of Escherichia coli induces neurodegeneration in mice by acting as an amyloid
}

\author{
J. Joseph Sahaya Rajan - T. Chinnappan Santiago • \\ R. Singaravel $\cdot$ S. Ignacimuthu
}

Published online: 11 January 2016

(C) Springer Science+Business Media Dordrecht 2016

\section{Erratum to: Biotechnol Lett \\ DOI 10.1007/s10529-015-2025-8}

The authors wish to edit the legend text for Figure 4 in this article.

The online version of the original article can be found under doi:10.1007/s10529-015-2025-8.

J. Joseph Sahaya Rajan · T. Chinnappan Santiago .

R. Singaravel

Central Institute of Brackishwater Aquaculture, Chennai,

Tamil Nadu 600028, India

T. Chinnappan Santiago $\cdot$ S. Ignacimuthu $(\square)$

Division of Neurophysiology, Entomology Research Institute, Loyola College, Chennai, Tamil Nadu 600034,

India

e-mail: eriloyola@hotmail.com

S. Ignacimuthu

Deanship of Scientific Research, College of Science, King

Saud University, Riyadh, Kingdom of Saudi Arabia 

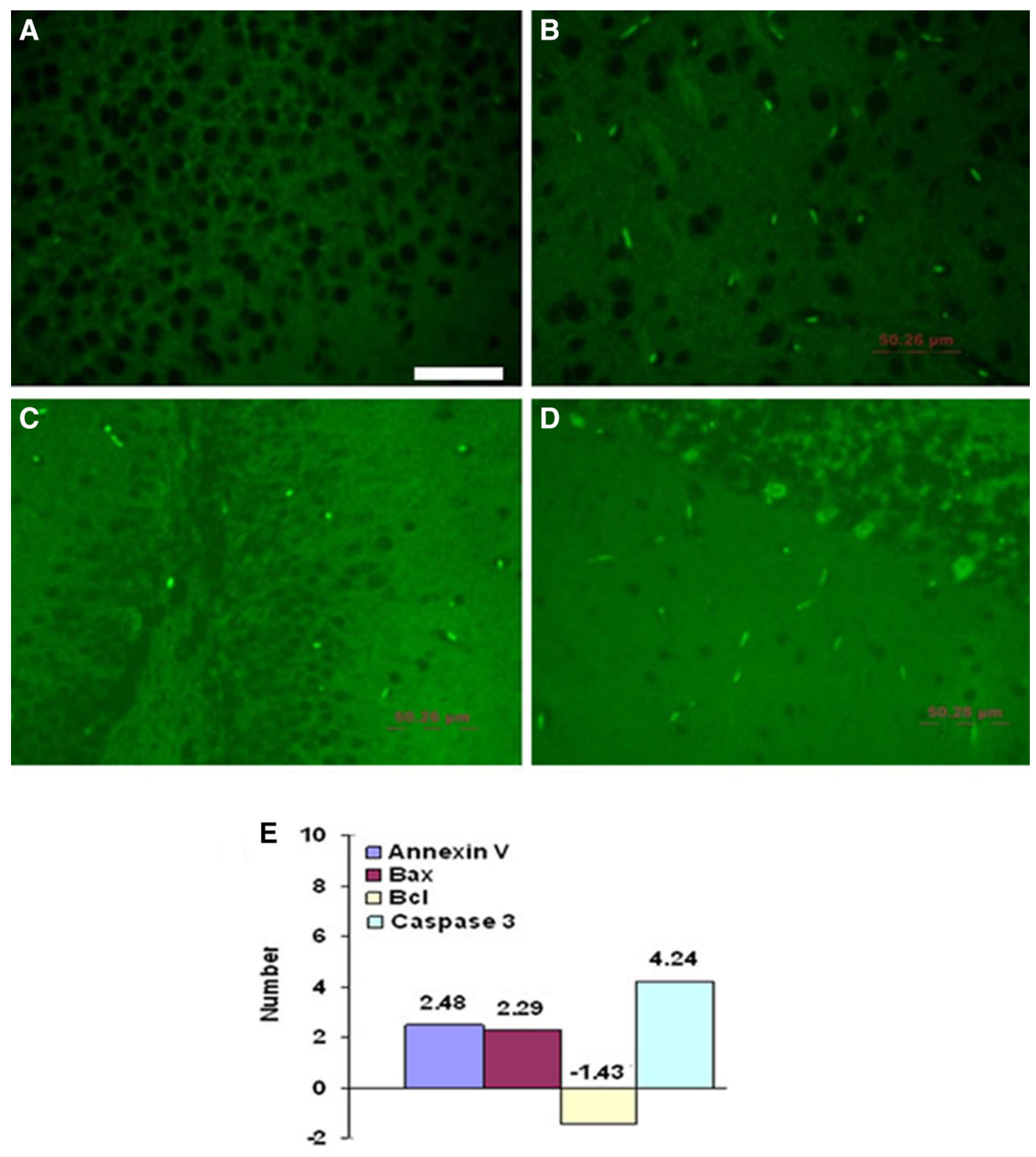

Fig. 4 Immunolocalization of porins in the mice brain. a 45 dpi control cortex did not react with porin antibodies and did not show any fluorescence. Porin treated 45 dpi cortex, hippocampus and cerebellum reacted with porin antibodies and showed fluorescence. Hippocampus showed less fluorescence compared to cortex and cerebellum (b-d). Real time PCR analysis showed upregulation and downregulation of apoptotic genes (e). Scale bar $50 \mu \mathrm{m}$. 